\title{
HIRING THE RIGHT CEO: HOW DOES THE TYPE OF CEO INDUSTRY EXPERIENCE AFFECT FIRM PERFORMANCE, FIRM RISK-TAKING BEHAVIOR, AND CEO COMPENSATION?
}

\author{
Candra Chahyadi* \\ Eastern Illinois University, USA \\ Trang Doan \\ Eastern Illinois University, USA \\ Junnatun Naym \\ Mississippi State University, USA
}

\begin{abstract}
This paper examines how the type of CEOs' industry experience (whether a CEO has cross-industry or specific-industry experience) on firm performance, firm risk-taking behavior, and their own compensation. We find that CEOs with cross-industry experience tend to relatively lower the firm performance as well as invest less on R\&D. On the other hand, CEOs with specific-industry experience lead firm to higher performance and invest more on $R \& D$ expenditures until it reaches a certain threshold, especially among high-growth firms. Total compensation paid to the CEO does not seem to be affected by the type of CEO industry experience. This paper contributes to the literature that examines the impact of CEO characteristics on firm outcomes and CEO compensation. One important business application of our paper is that to optimize firm performance, firms should hire CEOs with the length of specific-industry experience not beyond the threshold levels.
\end{abstract}

Keywords: CEO Industry Experience, Firm Performance, Firm Risk-Taking Behavior, CEO Compensation.

Received: 5 December 2020

Accepted:10 May 2021

https://doi.org/10.33736/ijbs.3762.2021

\section{INTRODUCTION}

Given the significant role that CEOs have in the corporate control and decision-making, a large body of academic research has been devoted to examining the relationship between CEO characteristics and firm outcomes. How CEO characteristics affect the corporate outcome has drawn attention of researchers in different areas, such as management (Karaevli, 2007; Bragaw \& Misangyi, 2017), accounting (Graham et al., 2013; Brockman et al., 2019), and finance (Cain \& McKeon, 2016; Bernile et al., 2017). The upper echelons literature postulates that differences in psychological characteristics, such as tenacity and grit, as well as the intangible personal assets,

- Corresponding author: 3016 Lumpkin Hall, 600 Lincoln Ave, Charleston, IL, USA; Phone: +1-217-581-6367; Email: cchahyadi@eiu.edu. 
such as knowledge and experience, of top executives would result in different organizational strategic choices (Hambrick \& Mason, 1984).

Bragaw and Misangyi (2017) explored the impact of CEO experience on firm performance and CEO compensation. They find that prior CEO experience does not lead to firm's better performance, but CEO experience tends to benefit CEO in the form of higher compensation. However, there are not many studies that have thoroughly examined how the type of CEO industry experience (whether a CEO has specific-industry experience or cross-industry experience) affects the corporate outcomes. CEOs' industry experience provides valuable network connections and useful insights that help CEOs better understand their industry's conditions and trends, so that they will be able to respond effectively to opportunities and threats arising from changing business environments.

To provide a deeper understanding on how CEO industry experience type affects firm outcomes, our study seeks to answer these questions: 1 . What is the impact CEOs' industry experience type on firm performance, firm risk-taking behavior, and CEOs' own compensation? 2. Do these relations depend on firm's characteristics such as growth opportunities?

Using a dataset on 1,127 CEOs of S\&P 1,500 companies during the period 1992-2017, we document significant impact of CEO industry experience type on firm performance and firm risktaking behavior but not on the CEO compensation while controlling for both firm and CEO characteristics in our analysis.

The contributions of our study to the corporate finance literature are as follows. First, our paper complements the growing branch of literature that examines CEO characteristics on firm performance. Our study suggests that the length of specific-industry experience positively affects firm performance but the impact becomes negative after a certain threshold level. Moreover, we find that hiring CEOs with cross-industry experience is not likely to help improve firm performance, rather adversely affects the firm performance. Our results extend the findings of prior studies and have important practical implications for CEO succession decisions.

Second, our paper complements the CEO compensation literature. Prior CEO compensation literature has examined how different firm characteristic variables (such as firm size, firm performance, level of corporate governance and incentive mechanism etc.) and CEO personal characteristics (such as military experience, tenure, education, etc.) on their own compensation. To the best of our knowledge, our paper is the first study to examine the connection between the type of CEO industry experience and the CEO compensation. We find weakly positive associations between the type of CEO industry experience and CEO compensation.

Third, our paper also contributes to the literature on firm risk-taking behavior. The existing literature has focused on factors that could drive a firm's decision to make risky investments. Surprisingly, the connection between the type of CEOs' industry experience and the firm risktaking behavior has not been studied extensively. We find that there is a non-monotonic association between the type of CEO industry experience and firm risk-taking behavior. We also find that hiring CEOs with cross-industry experience can result in the firm taking less risk, regardless the growth opportunity that the firm has. 
This paper is structured as follows: section 2 provides an overview of literature on CEO characteristics, particularly CEO industry experience, and testable hypotheses. Section 3 describes data and methods. The empirical analysis and findings are presented in section 4. Finally, section 5 concludes.

\section{LITERATURE REVIEW}

Boards can recruit outsider CEOs with the hope that outside CEOs can rejuvenate their struggling firms. Sometimes firms hire an outside CEO candidate because of the lack of qualified internal candidates or the need for infusion of new perspectives, skills, or knowledge. However, outside CEOs can be hired either from the same or a different industry. Investigating how firm performance, firm risk-taking behavior and CEO compensation are influenced by different types of CEO industry experience serves invaluable input for the board of directors overseeing the succession planning.

\subsection{CEO Industry Experience Type and Firm Performance}

Numerous studies have examined the relationship between firm performance and CEO characteristics (such as age, gender, tenure, educational and professional qualification). However, our paper specifically focuses on how CEO industry experience type affects firm performance.

Firms hire their CEOs from the same industry to learn from their peer firms and to speed up the CEO's adaptation period. However, CEO experience may act as "knowledge corridors," making it difficult for them to adjust their decision-making and act differently in their new work setting. Jobspecific experience gained from the last CEO job is likely to interfere with their performance in their new job. Hence, prior specific-industry experience could slow down learning because some knowledge and skills need to be "unlearned" before taking in new context. These opposite arguments lead to our first hypothesis:

\section{Hypothesis 1: There is a statistically significant relationship between CEOs' specific-industry experience and firm performance.}

Mueller et al. (2017) state that the relationship between CEO experience variety and firm performance is like inverted U-shaped which means that gaining experience from different firms and industries leads to higher firm performance initially but after a threshold, CEOs with crossindustry experience may lack depth and specialization, a shortcoming resulting in declining firm performance.

CEOs with cross-industry experience may be unfamiliar with the industry where their new firm is in, but they were hired because they had demonstrated superior leadership and managerial skills during their last tenure. CEOs with cross-industry experience are not deeply rooted in the industry and may lack a good understanding of opportunities and threats, product lines, manufacturing process of the new firm. As a result, CEOs with cross-industry experience are less likely to initiate and implement new strategic changes that can boost up long-term firm performance. These reasonings lead to the following hypothesis:

Hypothesis 2: Firms hiring CEOs with cross-industry experience are likely to have lower firm performance. 


\subsection{CEO Industry Experience Type and Firm Risk-Taking Behavior}

A firm risk-taking behavior is highly influenced by its CEO's preferences and attitudes. Prior studies suggest that CEO characteristics significantly influence risky investment choices by firms. Malmendier and Tate (2005) examined the impact of overconfidence and other personal characteristics of CEO on investment decisions. Furthermore, Malmendier et al. (2011) suggest that CEO traits such as military service during early adulthood can induce firm risk-taking behaviors. On the contrary, Benmelech and Frydman (2015) find a negative relation between military CEOs and R\&D expenditures.

Hence, understanding the relation between $\mathrm{CEO}$ characteristics and firm risk-taking behavior helps the board making better strategic decisions regarding hiring a new CEO. Our study contributes to the existing literature by shedding light on the less examined relation between CEO industry experience type and R\&D spending that serves as a proxy to the firm risk-taking behavior.

Other studies have explored how CEO characteristics influence firm risk taking. Chahyadi and Wineka (2019) find that outsider CEOs invest more in R\&D investment, less in capital expenditure and they use more leverage. Faccio et al. (2016) investigate the relation between CEO gender and corporate risk-taking. They find that female CEOs make less risky corporate choices than male CEOs. More risk-taking activities are also taken by younger CEOs and wealthier CEOs (Calvet \& Sodini, 2014).

Specific industry expertise and familiarity helps CEOs better navigate the risk-reward balance in the industry. Faleye et al. (2018) argue that firms with directors possessing industry expertise invest more on R\&D. Yung and Chen (2018) find that high ability managers are more receptive to risktaking and tend to spend more on R\&D and less on capital expenditure. Specific-industry experience may act as an operational template that is likely to improve CEOs' decisiveness. Gaining specific-industry experience over time gives CEOs more knowledge and confidence in their ability to make strategic choices. These arguments lead to our next hypothesis:

\section{Hypothesis 3: $C E O$ specific-industry experience is more likely to result in higher $R \& D$ spending.}

Due to the idiosyncratic differences among industries, CEO cross-industry experience may not be readily transferable to the new setting. Prior research suggests that moving across industries constrains the extent to which CEOs can apply more general managerial skills across different sectors (Bailey \& Helfat, 2003). CEOs with cross-industry experience may not have much experience in the new industry so that they may feel less confident in making significant R\&D investment in the new firm.

R\&D investments are long-term investment and not only are payoffs very uncertain but also often take many years. This may not align with the interests of new CEOs who need to show their worth not too long after their appointment. Recognizing risks and rewards of potential investments gets easier for CEOs with industry knowledge (Drobetz et al., 2018). It can be argued that if CEOs lack an in-depth understanding of the industry-fundamentals, such as the effect of microeconomic and macroeconomic factors, they will also lack the knowledge necessary for effective longer-term strategies such as R\&D spending. These arguments lead to our next hypothesis as follows: 


\section{Hypothesis 4: CEOs with cross-industry experience are more likely to invest less in $R \& D$ at their new firm.}

\subsection{CEO Industry Experience Type and CEO Compensation}

Like other CEO characteristics, CEO industry experience type may have significant implications on the CEO compensation. However, the literature examining the relation between CEO compensation and their industry experience type is far from being complete. Our study contributes to the existing literature by investigating how specific-industry and cross-industry experiences influence CEO compensation.

Prior literature has tested many relations between CEO characteristics and CEO compensation. Fee and Hadlock (2003) find that CEOs working in firms with above-average stock price performance are more likely to receive higher pay when they got hired by their new firms. Frydman and Jenter (2010) state that CEO compensation is affected both by managerial power and competitive market forces. Since industry-specific skills may not be easily transferable, CEOs who spent their career in a single industry are more likely to have little bargaining power in the competitive labor market. As a result, firms are less likely to pay a premium to CEOs with specific-industry experience. Hence, we hypothesize that:

\section{Hypothesis 5: CEO specific-industry experience leads to lower CEO compensation.}

CEO cross-industry experience in any executive roles help them advance ahead of their peers. Hiring organizations normally provide higher compensation to outsider CEOs than to insider CEOs (Murphy \& Zábojnik, 2004). This study also finds that outsider CEOs earn approximately 15.3 percent more than CEOs who were promoted internally. The literature suggest that this increase in compensation can be somewhat attributed to the recent increase in the demand for generalist skills. Custódio et al. (2013) shed light on why generalist CEOs earn pay premium and opine that firms that hire generalist CEOs pay significant compensation premium when their firms or the industry the firms belong to are going through mergers and acquisitions, financial distress, restructuring, or changing business conditions.

\section{Hypothesis 6: $C E O$ cross-industry general managerial experience leads to higher CEO compensation.}

\section{METHODOLOGY}

\subsection{Sample and Data}

The sample consists of CEO data collected from the Standard \& Poor's Execucomp database between 1992 and 2017. An executive is classified as CEO if the Execucomp's "titleann" contains phrases such as "CEO" or "Chief Executive Officer" or "Principal Executive Officer". We exclude utility companies (SIC 4900-4999) because they are subject to certain regulation and financial services firms (SIC 6000-6999) because they have distinct financial structure. We collect accounting data from Compustat over the same time period (1992-2017) and stock return data from the Center for Research in Security Prices (CRSP) database. To determine the type of industry 
experience of a CEO, we hand collect the experience data. We thoroughly examined the career history of all CEOs and we determine that a CEO has cross-industry experience if the CEO has worked in any different industry before working at the current company. We define that a different industry is any industries that do not have the same first three SIC code digits as the industry where the current firm is located in. The final sample consists of 4,816 CEO firm-year observations.

\subsection{Variables}

\subsubsection{Dependent variables}

We test the impact of CEO industry experience type on three dependent variables: firm performance, firm risk-taking behavior and CEO compensation. To focus on operational performance instead of market-based performance, we use Return on Asset (ROA) as a measure of performance. We measure risk-taking behavior by the ratio of capital expenditure to total assets and the ratio of R\&D expenditure to sales. CEO total compensation is the proxy for compensation. All dependent variables are measure at time $t+1$ to prevent reverse causality.

\subsubsection{Test Variables}

We designate a CEO as having specific-industry experience if he/she has experience in top executive positions (such as $\mathrm{CEO}, \mathrm{CFO}, \mathrm{COO}$ etc.) in any firms in the same industry. Custódio et al. (2013) classified these CEOs as specialist CEOs who spent their whole professional career in a single industry, and they possess deep specific-industry experience. On the other hand, generalist CEOs are those with general managerial experience or skills, that are not specific to any industry or firm.

Cross-Industry Experience: The variable "Multi-Ind" refers to the presence or absence of general managerial experience. CEOs are classified as CEOs with general managerial experience if they have experience in any of the following roles: CEO, CFO, President, Executive Vice President, Senior Vice President, Corporate Vice President, Managing Director, General Manager, Executive Director, Chairman, Vice Chairman with administration duties, or any C-Suite executive in other S\&P 500 companies. We measure "Multi_Ind" variable as the number of different industry a CEO has worked in the forementioned positions.

Specific-Industry Experience: The variable "Specific_Ind" refers to the presence or absence of specific-industry experience. We measure "Specific_Ind" as the length of experience in the same industry (those with the same first three SIC code digits). To capture the non-linear effect of CEO specific-industry experience, we include the squred "Specific_Ind" variable in our research model.

\subsubsection{Firm Control variables}

Our research model includes several firm-specific control variables that may influence firm performance, firm risk-taking, and CEO compensation. These control variables include firm size, leverage, growth opportunity, research and development (R\&D) expenditure, dividends, capital expenditure, return volatility, etc. Firm size, measured as the natural logarithm of total assets, is used to control the scale issues. Leverage is measured as the ratio of long-term debt to total assets. 
Market to book ratio (MTB), which proxies for firm growth opportunities, is measured as the ratio of market value of equity to book value of equity. $R \& D$ is computed as the ratio of $R \& D$ expenditure to sales. Dividends, measured as the sum of dividends from preferred and common stock scaled by total assets, gauge the degree of financial constraints (where the higher the ratio, the lower the financial constraints the firm is subject to). Capital expenditure represents the ratio of capital expenditure to total assets. To measure risk, we use stock return volatility from daily return data as a measure of risk. Volatility is defined as the sum of the squared residual from the Fama and French's (1993) three-factor model. Net working capital is used to measure the cash and operating liquidity position of the firm.

\subsubsection{CEO Control Variables}

To control for CEO characteristics, we collect their biographical information such as gender, tenure, and educational background. To quantify the educational background, we create two dummy variables. One dummy variable is "MBA" which takes the value of one if the CEO has an MBA, and zero otherwise. Another dummy variable is "PhD_Masters" which takes the value of one if the CEO has either a master's or Ph.D. degree, and zero otherwise. "CEO Tenure" indicates the length of time that CEOs has served in the current position. To control for gender, we take "Female" dummy variable which takes the value of one if the CEO is female, and zero otherwise. The biographical information is collected from multiple sources such as Execucomp, Bloomberg.com, NNDB.com, Referenceforbusiness.com, Prabook.com, MarketScreener.com and other publicly available sources. Table 5 provides definition or measurement of the variables used in this paper.

\subsection{Research Methods}

Using OLS, this paper examines the impact of CEO industry experience type on dependent variables. Moreover, to control for any unobserved effects, we include the industry fixed-effect and year fixed-effect using the industry dummies and year dummies. To examine the impact of CEO's industry experience type on corporate outcomes in different business environments, we also categorize the sample into high-growth and low-growth firms based on the sample-median marketto-book ratio (MTB) in each year. P-values are calculated using White's heteroskedasticitycorrected standard errors. To limit the influence of outliers and misrecorded data, variables are winsorized at the $1 \%$ at both tails. To check the robustness of our empirical result, we include CEO's age in the model and all the results are maintained.

\section{RESULTS AND DISCUSSION}

\subsection{Descriptive Statistics}

Table 1 summarizes the descriptive statistics for key variables used in our study. Out of 1,127 CEOs in the sample, 35\% (393 CEOs) have an MBA degree and 19\% (219 CEOs) have either a master's or a Ph.D. degree. 25\% (287 CEOs) have work experience in more than one industry while the average length of specific-industry experience is 18.02 years. Female CEOs constitute only $12 \%$ (130) of our sample. The average CEO has tenure in executive position for 6.3 years. The longest serving CEO has been in executive position for 49 years. Average market to book ratio is 2.42 . Average ROA is $11.86 \%$. Dividend, fixed asset, capital expenditure and debt are $1.99 \%$, 
$28.50 \%, 5.56 \%$ and $22.92 \%$ of total asset respectively, on average. The average R\&D to total sales ratio is 6.24 .

Table 1: Descriptive Statistics

\begin{tabular}{cccccc}
\hline \hline Variable & Mean & Median & Maximum & Minimum & Std Dev \\
\hline Multi_Ind & N/A & N/A & 1.00 & 0.00 & N/A \\
Specific_Ind & 18.02 & 17 & 55 & 1 & 9.14 \\
Female & N/A & N/A & 1.00 & 0.00 & N/A \\
Tenure & 6.3 & 5 & 49 & 0 & 7.1 \\
MBA & N/A & N/A & 1.00 & 0.00 & N/A \\
PhD_Masters & N/A & N/A & 1.00 & 0.00 & N/A \\
MTB & 2.42 & 1.89 & 43.85 & 0.55 & 1.92 \\
Volatility & 9.05 & 7.63 & 82.57 & 1.74 & 5.57 \\
Firm_Perf & 11.86 & 11.65 & 48.19 & -240.38 & 9.56 \\
Capex & 5.56 & 4.01 & 46.83 & 0.00 & 5.13 \\
R\&D & 6.24 & 0.54 & $2,315.29$ & 0.00 & 39.57 \\
Firm Size & $16,848.08$ & $7,168.80$ & $22,0217.00$ & 51.04 & $25,001.78$ \\
Leverage & 22.92 & 21.06 & 170.48 & 0.00 & 17.06 \\
Dividend & 1.99 & 1.21 & 64.45 & 0.00 & 3.03 \\
NWC & -138.31 & 70.90 & 2016 & -8240 & $1,183.95$ \\
Fixed Asset & 28.50 & 21.21 & 93.39 & 0.17 & 22.51 \\
\hline \hline
\end{tabular}

\subsection{Results on CEO Industry Experience Type and Firm Performance}

In this section, we test hypothesis 1 and 2 regarding the association between CEO industry experience type and firm performance. We employ model 1 to capture the impact of specificindustry experience on firm performance. The model control for selected CEO characteristics and firm-level accounting variables. We also include the squared specific-industry variable to look at whether there exists any non-linear relationship:

$$
\begin{aligned}
& \text { Firm_Perf } f_{i, t+1}=B_{0}+B_{1} \text { Specific_Ind }_{i, t}+B_{2} \text { Specific_Ind_Sq }{ }_{i, t}+B_{3-6}(C E O \text { controls })_{i, t} \\
& +\mathrm{B}_{7} \mathrm{MTB}_{\mathrm{i}, \mathrm{t}}+\mathrm{B}_{8} \text { Volatility }_{\mathrm{i}, \mathrm{t}}+\mathrm{B}_{9} \text { Capex }_{\mathrm{i}, \mathrm{t}}+\mathrm{B}_{10} \mathrm{R} \& \mathrm{D}_{\mathrm{i}, \mathrm{t}} \\
& +\mathrm{B}_{11} \text { Firm Size }_{\mathrm{i}, \mathrm{t}}+\mathrm{B}_{12} \text { Leverage }_{\mathrm{i}, \mathrm{t}}+\mathrm{B}_{13} \text { Dividends }_{\mathrm{i}, \mathrm{t}}+\mathrm{B}_{14} \mathrm{NWC}_{\mathrm{i}, \mathrm{t}} \\
& +\mathrm{B}_{15} \text { Fixed Assets } \mathrm{s}_{\mathrm{i}, \mathrm{t}}+\varepsilon_{\mathrm{i}, \mathrm{t}}
\end{aligned}
$$

Model 2 analyzes the impact of multiple-industry experience (or cross-industry experience) on firm performance controlling for other CEO characteristics and firm-level accounting variables:

$$
\begin{aligned}
\text { Firm_Perf }_{i, t+1}= & B_{0}+B_{1} \text { Multi_Ind }_{i, t}+B_{2-5}(\text { CEO controls })_{i, t}+B_{6} \text { MTB }_{i, t}+B_{7} \text { Volatility }_{i, t} \\
& +B_{8} \text { Capex }_{i, t}+B_{9} \text { R }_{2} D_{i, t}+B_{10} \text { Firm Size } \\
& +B_{12} \text { Dividends }_{i, t}+B_{11} \text { Leverage }_{13} \text { NWC }_{i, t}+B_{14} \text { Fixed Assets } \\
&
\end{aligned}
$$


Table 2: Impact of CEO industry Experience on Firm Performance

\begin{tabular}{|c|c|c|c|c|c|c|}
\hline & All firms & $\begin{array}{l}\text { High-growth } \\
\text { firms }\end{array}$ & $\begin{array}{l}\text { Low-growth } \\
\text { firms }\end{array}$ & All firms & $\begin{array}{l}\text { High-growth } \\
\text { firms }\end{array}$ & $\begin{array}{l}\text { Low-growth } \\
\text { firms }\end{array}$ \\
\hline & (1) & (2) & (3) & (4) & (5) & (6) \\
\hline Multi-ind & & & & $\begin{array}{c}-0.829^{* * * *} \\
(0.01)\end{array}$ & $\begin{array}{l}-0.402 \\
(0.35)\end{array}$ & $\begin{array}{c}-0.810^{*} \\
(0.07)\end{array}$ \\
\hline Specific_ind & $\begin{array}{l}0.271^{\text {**** }} \\
(<.0001)\end{array}$ & $\begin{array}{c}0.252^{* * *} \\
(0.00)\end{array}$ & $\begin{array}{l}0.115^{*} \\
(0.09)\end{array}$ & & & \\
\hline Specific_ind_sq & $\begin{array}{l}-0.007^{* * * *} \\
(<.0001)\end{array}$ & $\begin{array}{c}-0.007^{* * * *} \\
(0.00)\end{array}$ & $\begin{array}{c}-0.004^{* *} \\
(0.03)\end{array}$ & & & \\
\hline Female & $\begin{array}{l}0.515 \\
(0.59)\end{array}$ & $\begin{array}{l}-0.122 \\
(0.92)\end{array}$ & $\begin{array}{l}0.518 \\
(0.74)\end{array}$ & $\begin{array}{l}0.442 \\
(0.65)\end{array}$ & $\begin{array}{l}-0.516 \\
(0.67)\end{array}$ & $\begin{array}{l}0.585 \\
(0.71)\end{array}$ \\
\hline Tenure & $\begin{array}{l}0.085^{* * * *} \\
(<.0001)\end{array}$ & $\begin{array}{l}0.059^{* * *} \\
(0.03)\end{array}$ & $\begin{array}{c}0.095^{* * * *} \\
(0.00)\end{array}$ & $\begin{array}{c}0.070^{* * * *} \\
(0.00)\end{array}$ & $\begin{array}{l}0.059^{* * *} \\
(0.02)\end{array}$ & $\begin{array}{c}0.069^{* * * *} \\
(0.01)\end{array}$ \\
\hline MBA & $\begin{array}{c}-0.665^{* * * *} \\
(0.01)\end{array}$ & $\begin{array}{c}-0.912^{* *} \\
(0.02)\end{array}$ & $\begin{array}{l}0.078 \\
(0.83)\end{array}$ & $\begin{array}{c}-0.608^{* * *} \\
(0.02)\end{array}$ & $\begin{array}{c}-0.857^{* *} \\
(0.02)\end{array}$ & $\begin{array}{l}0.119 \\
(0.74)\end{array}$ \\
\hline PhD_Masters & $\begin{array}{l}-0.283 \\
(0.36)\end{array}$ & $\begin{array}{l}-0.545 \\
(0.20)\end{array}$ & $\begin{array}{l}-0.130 \\
(0.78)\end{array}$ & $\begin{array}{l}-0.260 \\
(0.41)\end{array}$ & $\begin{array}{l}-0.517 \\
(0.22)\end{array}$ & $\begin{array}{l}0.032 \\
(0.95)\end{array}$ \\
\hline MTB & $\begin{array}{l}1.145^{* * * *} \\
(<.0001)\end{array}$ & $\begin{array}{l}0.766^{* * *} \\
(<.0001)\end{array}$ & $\begin{array}{l}9.320^{* * * *} \\
(<.0001)\end{array}$ & $\begin{array}{l}1.156^{* * * *} \\
(<.0001)\end{array}$ & $\begin{array}{l}0.762^{* * * *} \\
(<.0001)\end{array}$ & $\begin{array}{l}9.382^{* * * *} \\
(<.0001)\end{array}$ \\
\hline Volatility & $\begin{array}{l}-0.347^{* * * *} \\
(<.0001)\end{array}$ & $\begin{array}{l}-0.390^{* * * *} \\
(<.0001)\end{array}$ & $\begin{array}{l}-0.166^{* * * *} \\
(<.0001)\end{array}$ & $\begin{array}{l}-0.353^{* * * *} \\
(<.0001)\end{array}$ & $\begin{array}{l}-0.395^{* * *} \\
(<.0001)\end{array}$ & $\begin{array}{l}-0.167^{* * * *} \\
(<.0001)\end{array}$ \\
\hline Capex & $\begin{array}{l}-0.035 \\
(0.34)\end{array}$ & $\begin{array}{l}0.068 \\
(0.22)\end{array}$ & $\begin{array}{l}-0.281^{* * * *} \\
(<.0001)\end{array}$ & $\begin{array}{l}-0.044 \\
(0.24)\end{array}$ & $\begin{array}{l}0.069 \\
(0.22)\end{array}$ & $\begin{array}{l}-0.293^{* * * *} \\
(<.0001)\end{array}$ \\
\hline $\mathrm{R} \& \mathrm{D}$ & $\begin{array}{l}-0.031^{* * * *} \\
(<.0001)\end{array}$ & $\begin{array}{l}-0.026^{* * *} \\
(<.0001)\end{array}$ & $\begin{array}{l}-0.279^{* * * *} \\
(<.0001)\end{array}$ & $\begin{array}{l}-0.031^{* * * *} \\
(<.0001)\end{array}$ & $\begin{array}{l}-0.025^{* * *} \\
(<.0001)\end{array}$ & $\begin{array}{l}-0.281^{* * * *} \\
(<.0001)\end{array}$ \\
\hline Firm size & $\begin{array}{c}-0.218^{*} \\
(0.09)\end{array}$ & $\begin{array}{l}0.308^{*} \\
(0.08)\end{array}$ & $\begin{array}{l}-0.197 \\
(0.34)\end{array}$ & $\begin{array}{c}-0.255^{* *} \\
(0.05)\end{array}$ & $\begin{array}{l}0.298^{*} \\
(0.09)\end{array}$ & $\begin{array}{l}-0.212 \\
(0.31)\end{array}$ \\
\hline Leverage & $\begin{array}{l}-0.071^{* * * *} \\
(<.0001)\end{array}$ & $\begin{array}{l}-0.090^{* * * *} \\
(<.0001)\end{array}$ & $\begin{array}{l}-0.022 \\
(0.14)\end{array}$ & $\begin{array}{l}-0.072^{* * * *} \\
(<.0001)\end{array}$ & $\begin{array}{l}-0.092^{* * * *} \\
(<.0001)\end{array}$ & $\begin{array}{l}-0.024 \\
(0.12)\end{array}$ \\
\hline Dividend & $\begin{array}{l}0.695^{* * *} \\
(<.0001)\end{array}$ & $\begin{array}{l}0.537^{* * * *} \\
(<.0001)\end{array}$ & $\begin{array}{l}0.132 \\
(0.37)\end{array}$ & $\begin{array}{l}0.690^{* * * *} \\
(<.0001)\end{array}$ & $\begin{array}{l}0.526^{* * * *} \\
(<.0001)\end{array}$ & $\begin{array}{l}0.125 \\
(0.40)\end{array}$ \\
\hline NWC & $\begin{array}{l}0.000 \\
(0.75)\end{array}$ & $\begin{array}{l}0.000 \\
(0.19)\end{array}$ & $\begin{array}{l}0.000 \\
(0.17)\end{array}$ & $\begin{array}{l}0.000 \\
(0.73)\end{array}$ & $\begin{array}{l}0.000 \\
(0.14)\end{array}$ & $\begin{array}{l}0.000 \\
(0.16)\end{array}$ \\
\hline Fixed asset & $\begin{array}{l}0.008 \\
(0.60)\end{array}$ & $\begin{array}{c}0.020 \\
(0.40)\end{array}$ & $\begin{array}{l}0.015 \\
(0.47)\end{array}$ & $\begin{array}{l}0.009 \\
(0.57)\end{array}$ & $\begin{array}{c}0.020 \\
(0.40)\end{array}$ & $\begin{array}{l}0.012 \\
(0.57)\end{array}$ \\
\hline Year and Ind. FEs & Yes & Yes & Yes & Yes & Yes & Yes \\
\hline Adj. $\mathrm{R}^{2}$ & 0.378 & 0.425 & 0.269 & 0.374 & 0.382 & 0.268 \\
\hline $\mathrm{N}$ & 4,816 & 2,525 & 2,291 & 4,816 & 2,525 & 2,291 \\
\hline
\end{tabular}

*, **, and *** indicate significance at 10\%, 5\%, and 1\% level, respectively. Numbers in parentheses are p-values.

Column 2 of table 2 reports the OLS results explaining the impact of CEO specific-industry experience on firm performance considering the full sample data set. The length of specificindustry experience positively affects firm performance. This may be because specific-industry knowledge is an important asset that helps CEOs understand factors that could have economic impact on business operations and earnings. In addition, previous specific-industry connections can provide valuable information that improves firm performance. This finding contradicts the result of Hamori and Koyuncu (2015) who find that CEOs with specific-industry experience are associated with significantly lower post-succession firm performance than CEOs with crossindustry experience. However, our result is consistent with the findings of Wang et al. (2016) who 
find that CEO prior experience in the same industry is positively related with future firm performance.

Next, we test the models for high-growth and low-growth firms and present the results in columns 3 and 4 of table 2 . We find the same conclusion for both high-growh and low-growth firms (despite lower statistical significance for the low-growth firms). This finding supports the view that experience in the same industry helps CEOs lead to better performance. This effect is statistically very signifcant in two out of three cases (full sample and high-growth) while the effect is significant at $10 \%$ level for the low-growth firms. Interestingly, the magnitude is the same for full sample and high-growth sample though a bit smaller for low-growth firms. This difference in coefficient between high-growth and low-growth firms might be driven by the fact that high-growth firms get higher sales turnover and revenue from new products in the market, leading to better firm performance measued by ROA.

Though gaining experience in the same industry has several positive expected effects, remaining in the same industry might have some negative effects as well. As indicated by the negative coefficient of the squared specific-industry variable, after a threshold level of 18.83 years, experience in the same industry leads to adverse effect on firm performance. One explanation is that as CEOs gain more experience in the same industry, it sometimes becomes difficult to think out of the box and deviate from industry norms in order to improve firm performance. Over time, they may have developed set assumptions about how decisions should be made. They are more likely to repeat the similar course of actions even in different situations: a phenomenon called negative transfer of learning (Hamori \& Koyuncu, 2015). Jobs in the same industry may share superficial similarities but they can also have structural differences (Dokko et al., 2009). This limits the beneficial effects of specific-industry experience. In another word, related work experience for a long time could have a negative effect on firm performance since prior industry experience of CEOs may also bring inflexibilities that act as baggage and push down their ability to respond to new situation. Overall, our finding supports hypothesis 1 .

Table 2 also describes the OLS results explaining the impact of CEO cross-industry experience on firm performance considering full, high-growth, and low-growth samples in columns 5, 6, and 7 respectively. For the full sample, the negative coefficient of Multi_Ind variable indicates that hiring CEOs with cross-industry experience is not likely to help improve firm performance, rather adversely affects firm performance. This evidence supports our second hypothesis which predicts that CEOs with cross-industry experience will negatively influence firm performance. Then, when we run regressions separately for the two sub-samples, we find that cross-industry experience of CEOs affects firm performance negatively for both high-growth and low-growth firms but the effects are statistically less significant than that in the full sample. Hence, the hypothesis predicting the negative association between CEO cross-industry experience and firm performance is partially supported empirically (for the full sample but not for the sub-samples). This effect is mostly driven by the fact that CEO with multiple industry experience may lack critical industry-specific knowledge. It is also challenging for hiring firms to establish good fit between the human capital of CEOs with multiple industry experience and the culture of the hiring firms. 


\subsection{Results on CEO Industry Experience Type and Risk-Taking Behavior}

Since R\&D spending represents a long-term investment that is considerably risky with high failure rates (e.g., Mansfield, 1968; Barker \& Mueller, 2002; Chen \& Miller, 2007; Zhang, 2015), we use R\&D expenditure as a proxy for risk-taking behavior and use it as the dependent variable. Model 3 reports the OLS regression model used to assess the association between CEO specificindustry experience and R\&D.

$$
\begin{aligned}
& \text { R\&D }_{\mathrm{i}, \mathrm{t}+1}= \mathrm{B}_{0}+\mathrm{B}_{1} \text { Specific_Ind }_{\mathrm{i}, \mathrm{t}}+\mathrm{B}_{2} \text { Specific_Ind }_{\mathrm{i}, \mathrm{t}}+\mathrm{B}_{3-6}\left(\text { CEO controls }_{\mathrm{i}, \mathrm{t}}\right. \\
&+\mathrm{B}_{7} \text { MTB }_{\mathrm{i}, \mathrm{t}}+\mathrm{B}_{8} \text { Volatility }_{\mathrm{i}, \mathrm{t}}+\mathrm{B}_{9} \text { Firm__Perf }_{\mathrm{i}, \mathrm{t}}+\mathrm{B}_{10} \text { Capex }_{\mathrm{i}, \mathrm{t}} \\
&+\mathrm{B}_{11} \text { Firm Size }_{\mathrm{i}, \mathrm{t}}+\mathrm{B}_{12} \text { Leverage }_{\mathrm{i}, \mathrm{t}}+\mathrm{B}_{13} \text { Dividends }_{\mathrm{i}, \mathrm{t}}+\mathrm{B}_{14} \text { NWC }_{\mathrm{i}, \mathrm{t}} \\
&+\mathrm{B}_{15} \text { Fixed Assets } \\
& \mathrm{i}, \mathrm{t}
\end{aligned}
$$

Controlling for the selected CEO characteristics and accounting variables, model 4 looks at how multiple-industry experience may affect R\&D:

\begin{tabular}{|c|c|c|c|c|c|c|}
\hline & All firms & $\begin{array}{l}\text { High-growth } \\
\text { firms } \\
\end{array}$ & $\begin{array}{l}\text { Low-growth } \\
\text { firms }\end{array}$ & All firms & $\begin{array}{l}\text { High-growth } \\
\text { firms } \\
\end{array}$ & $\begin{array}{l}\text { Low-growth } \\
\text { firms }\end{array}$ \\
\hline & (1) & (2) & (3) & (4) & (5) & (6) \\
\hline Multi-ind & & & & $\begin{array}{c}-5.591^{\text {**** }} \\
(0.00)\end{array}$ & $\begin{array}{c}-9.160^{* * *} \\
(0.01)\end{array}$ & $\begin{array}{l}-1.103^{*} \\
(0.07)\end{array}$ \\
\hline Specific_ind & $\begin{array}{c}0.929^{* * * *} \\
(0.00)\end{array}$ & $\begin{array}{l}1.977^{* * * *} \\
(0.00)\end{array}$ & $\begin{array}{l}-0.004 \\
(0.96)\end{array}$ & & & \\
\hline Specific_ind_sq & $\begin{array}{c}-0.021^{* * * *} \\
(0.00)\end{array}$ & $\begin{array}{c}-0.043^{* * *} \\
(0.00)\end{array}$ & $\begin{array}{l}-0.001 \\
(0.71)\end{array}$ & & & \\
\hline Female & $\begin{array}{l}1.431 \\
(0.80)\end{array}$ & $\begin{array}{l}7.336 \\
(0.43)\end{array}$ & $\begin{array}{l}-1.024 \\
(0.62)\end{array}$ & $\begin{array}{l}0.254 \\
(0.96)\end{array}$ & $\begin{array}{l}2.460 \\
(0.79)\end{array}$ & $\begin{array}{l}-0.711 \\
(0.73)\end{array}$ \\
\hline Tenure & $\begin{array}{l}0.114 \\
(0.34)\end{array}$ & $\begin{array}{l}-0.097 \\
(0.65)\end{array}$ & $\begin{array}{c}0.094^{* * *} \\
(0.02)\end{array}$ & $\begin{array}{l}0.147 \\
(0.18)\end{array}$ & $\begin{array}{l}0.026 \\
(0.89)\end{array}$ & $\begin{array}{l}0.069^{*} \\
(0.06)\end{array}$ \\
\hline MBA & $\begin{array}{l}-2.809^{*} \\
(0.07)\end{array}$ & $\begin{array}{c}-6.124^{* * *} \\
(0.04)\end{array}$ & $\begin{array}{l}0.038 \\
(0.94)\end{array}$ & $\begin{array}{c}-2.662^{*} \\
(0.08)\end{array}$ & $\begin{array}{c}-5.741^{* *} \\
(0.05)\end{array}$ & $\begin{array}{l}0.091 \\
(0.85)\end{array}$ \\
\hline PhD_Masters & $\begin{array}{l}10.373^{* * * *} \\
(<.0001)\end{array}$ & $\begin{array}{l}15.313^{* * * *} \\
(<.0001)\end{array}$ & $\begin{array}{c}2.243^{\text {**** }} \\
(0.00)\end{array}$ & $\begin{array}{l}10.439^{* * *} \\
(<.0001)\end{array}$ & $\begin{array}{l}14.953^{* * *} \\
(<.0001)\end{array}$ & $\begin{array}{c}2.410^{* * * *} \\
(0.00)\end{array}$ \\
\hline MTB & $\begin{array}{c}1.602^{* * * *} \\
(0.00)\end{array}$ & $\begin{array}{l}1.240^{* * *} \\
(0.05)\end{array}$ & $\begin{array}{l}0.256 \\
(0.78)\end{array}$ & $\begin{array}{c}1.566^{* * * *} \\
(0.00)\end{array}$ & $\begin{array}{l}1.149^{*} \\
(0.07)\end{array}$ & $\begin{array}{l}0.243 \\
(0.79)\end{array}$ \\
\hline Volatility & $\begin{array}{l}0.257^{*} \\
(0.10)\end{array}$ & $\begin{array}{l}0.511^{*} \\
(0.10)\end{array}$ & $\begin{array}{l}0.072 \\
(0.14)\end{array}$ & $\begin{array}{l}0.243 \\
(0.12)\end{array}$ & $\begin{array}{l}0.479 \\
(0.12)\end{array}$ & $\begin{array}{l}0.074 \\
(0.12)\end{array}$ \\
\hline Capex & $\begin{array}{l}-0.122 \\
(0.57)\end{array}$ & $\begin{array}{l}-0.202 \\
(0.64)\end{array}$ & $\begin{array}{l}-0.049 \\
(0.45)\end{array}$ & $\begin{array}{l}-0.137 \\
(0.53)\end{array}$ & $\begin{array}{l}-0.219 \\
(0.62)\end{array}$ & $\begin{array}{l}-0.061 \\
(0.35)\end{array}$ \\
\hline Firm_Perf & $\begin{array}{l}-1.143^{* * *} \\
(<.0001)\end{array}$ & $\begin{array}{l}-1.605^{* * *} \\
(<.0001)\end{array}$ & $\begin{array}{l}-0.189^{* * *} \\
(<.0001)\end{array}$ & $\begin{array}{l}-1.132^{* * * *} \\
(<.0001)\end{array}$ & $\begin{array}{l}-1.593^{* * *} \\
(<.0001)\end{array}$ & $\begin{array}{l}-0.189^{* * *} \\
(<.0001)\end{array}$ \\
\hline
\end{tabular}

$$
\begin{aligned}
{\mathrm{R} \& \mathrm{D}_{\mathrm{i}, \mathrm{t}+\mathrm{t}}=} & \mathrm{B}_{0}+\mathrm{B}_{1} \text { Multi_Ind } \mathrm{i}_{\mathrm{i}, \mathrm{t}}+\mathrm{B}_{2-5}(\text { CEO controls })_{\mathrm{i}, \mathrm{t}}+\mathrm{B}_{6} \text { MTB }_{\mathrm{i}, \mathrm{t}} \\
& +\mathrm{B}_{7} \text { Volatility }_{\mathrm{i}, \mathrm{t}}+\mathrm{B}_{8} \text { Firm_Perf }_{\mathrm{i}, \mathrm{t}}+\mathrm{B}_{9} \text { Capex }_{\mathrm{i}, \mathrm{t}}+\mathrm{B}_{10} \text { Firm Size }_{\mathrm{i}, \mathrm{t}} \\
& +\mathrm{B}_{11} \text { Leverage }_{\mathrm{i}, \mathrm{t}}+\mathrm{B}_{12} \text { Dividends }_{\mathrm{i}, \mathrm{t}}+\mathrm{B}_{13} \text { NWC }_{\mathrm{i}, \mathrm{t}}+\mathrm{B}_{14} \text { Fixed Assets }_{\mathrm{i}, \mathrm{t}} \\
& +\varepsilon_{\mathrm{i}, \mathrm{t}}
\end{aligned}
$$

Table 3: Impact of CEO Industry Experience on R\&D 
Firm Risk-Taking Behavior, and Ceo Compensation?

\begin{tabular}{lcccccc}
\hline \hline Firm size & $-4.553^{* * * *}$ & $-3.472^{* * *}$ & $-2.208^{* * *}$ & $-4.566^{* * *}$ & $-3.464^{* * *}$ & $-2.196^{* * *}$ \\
& $(<.0001)$ & $(0.01)$ & $(<.0001)$ & $(<.0001)$ & $(0.01)$ & $(<.0001)$ \\
Leverage & $0.673^{* * *}$ & $1.139^{* * *}$ & $-0.039^{*}$ & $0.669^{* * *}$ & $1.133^{* * *}$ & $-0.041^{* * *}$ \\
& $(<.0001)$ & $(<.0001)$ & $(0.06)$ & $(<.0001)$ & $(<.0001)$ & $(0.05)$ \\
Dividend & 0.231 & -0.145 & -0.175 & 0.228 & -0.185 & -0.201 \\
& $(0.50)$ & $(0.78)$ & $(0.38)$ & $(0.50)$ & $(0.72)$ & $(0.31)$ \\
NWC & $-0.002^{* *}$ & -0.001 & $-0.001^{* * *}$ & $-0.002^{* *}$ & -0.001 & $-0.001^{* * *}$ \\
& $(0.03)$ & $(0.55)$ & $(0.00)$ & $(0.03)$ & $(0.61)$ & $(0.00)$ \\
Fixed asset & $-0.208^{* *}$ & $-0.532^{* * *}$ & -0.005 & $-0.206^{* *}$ & $-0.485^{* * *}$ & -0.009 \\
& $(0.02)$ & $(0.00)$ & $(0.87)$ & $(0.02)$ & $(0.01)$ & $(0.73)$ \\
\hline Year and Ind. FEs & Yes & Yes & Yes & Yes & Yes & Yes \\
Adj. R & 0.168 & 0.199 & 0.310 & 0.168 & 0.198 & 0.311 \\
$\mathrm{~N}$ & 4,816 & 2,525 & 2,291 & 4,816 & 2,525 & 2,291 \\
\hline \hline
\end{tabular}

$*, * *$, and $* * *$ indicate significance at 10\%, 5\%, and 1\% level, respectively. Numbers in parentheses are p-values.

Table 3 presents results on the association between R\&D and the type of CEO industry experience. Columns 2, 3, and 4 show the impact of specific-industry experience on R\&D controlling for other CEO characteristics and firm-level variables. Length of CEO experience in the same industry positively affects R\&D expenditure of firms considering full sample and the high-growth firms but negative for the low-growth firms. The negative coefficient for the low-growth firms is statistically insignificant. This finding partially supports our third hypothesis predicting positive association between CEO specific-industry experience and R\&D expenditure. One possible explanation is that CEOs who have served for long in an industry know better about that industry which makes them more confident to invest more in R\&D. However, as indicated by the negative coefficient of the squared Specific_Ind variable, after a vertex point of 24.13 years of experience in the same industry, more experienced CEOs start investing less in R\&D activities. This finding gives the impression that CEOs with more specific-industry experience become conservative during the later years of their executive career and are likely to underinvest in risky R\&D activities. This finding is in line with the finding of Ryan Jr and Wiggins III (2002) who argue that the relation between industry experience and risk-taking behavior is not linear. Rather, there is a non-monotonic inverted Ushaped relationship between these two variables. The magnitude of coefficient is higher for highgrowth firms compared to that of low-growth firms though the impact on low-growth firms' R\&D is not statistically significant. This might be because CEOs in high-growth firms recognize the importance of maintaining high $\mathrm{R} \& \mathrm{D}$ investment to continue their high growth. This result reinstates the idea that high-growth firms have greater R\&D intensity.

Table 3 also shows the effect of CEO multiple-industry experience on R\&D. For full and highgrowth samples, we find statistically significant negative coefficient of Multi-Ind variable indicates that hiring CEOs with multi-industry experience (or cross-industry experience) is likely to reduce R\&D investment. Since firm structure, industry growth, and ownership have significant moderating role in influencing managerial risk-taking (Hoskisson et al., 2017), we look at how the scenario changes if we analyze high-growth and low-growth firms separately. We find that the coefficient for the high-growth firms is negative and very significant but it is insignificantly negative for the low-growth firms. Overall, this evidence mostly supports our fourth hypothesis which predicts that CEOs with cross-industry experience will invest less on R\&D expenditure. 


\subsection{Results on CEO Industry Experience Type and CEO Compensation}

CEO industry tenure reflects CEOs' skills and knowledge. With this theoretical background, we test whether CEO industry experience type is a significant determinant of CEO compensation. To explore the influence of CEO specific-industry experience on CEO compensation, we employ model 5.

$$
\begin{aligned}
& \text { Compensation }{ }_{\mathrm{i}, t+1}=\mathrm{B}_{0}+\mathrm{B}_{1} \text { Specific_Ind }_{\mathrm{i}, \mathrm{t}}+\mathrm{B}_{2} \text { Specific_Ind }_{\mathrm{i}, \mathrm{t}}+\mathrm{B}_{3-\mathrm{G}}(\mathrm{CEO} \text { controls })_{\mathrm{i}, \mathrm{t}} \\
& +\mathrm{B}_{7} \mathrm{MTB}_{\mathrm{i}, \mathrm{t}}+\mathrm{B}_{8} \text { Volatility }_{\mathrm{i}, \mathrm{t}}+\mathrm{B}_{9} \text { Firm_Perf }_{\mathrm{i}, \mathrm{t}}+\mathrm{B}_{10} \text { Capex }_{\mathrm{i}, \mathrm{t}} \\
& +\mathrm{B}_{11} \text { R\&D } \mathrm{D}_{\mathrm{i}, \mathrm{t}}+\mathrm{B}_{12} \text { Firm Size }_{\mathrm{i}, \mathrm{t}}+\mathrm{B}_{13} \text { Leverage }_{\mathrm{i}, \mathrm{t}}+\mathrm{B}_{14} \text { Dividends }_{\mathrm{i}, \mathrm{t}} \\
& +\mathrm{B}_{15} \mathrm{NWC}_{\mathrm{i}, \mathrm{t}}+\mathrm{B}_{16} \text { Fixed Assets } \mathrm{i,t}+\mathrm{e}_{\mathrm{i}, \mathrm{t}}
\end{aligned}
$$

Model 6 reports the impact of multiple-industry experience on CEO compensation:

\begin{tabular}{|c|c|c|c|c|c|c|}
\hline & All firms & $\begin{array}{l}\text { High-growth } \\
\text { firms } \\
\end{array}$ & $\begin{array}{c}\text { Low-growth } \\
\text { firms } \\
\end{array}$ & All firms & $\begin{array}{l}\text { High-growth } \\
\text { firms } \\
\end{array}$ & $\begin{array}{c}\text { Low-growth } \\
\text { firms } \\
\end{array}$ \\
\hline & (1) & (2) & (3) & (4) & (5) & (6) \\
\hline Multi-ind & & & & $\begin{array}{l}0.078 \\
(0.14)\end{array}$ & $\begin{array}{l}0.062 \\
(0.48)\end{array}$ & $\begin{array}{l}0.002 \\
(0.97)\end{array}$ \\
\hline Specific_ind & $\begin{array}{l}0.009 \\
(0.28)\end{array}$ & $\begin{array}{l}0.018 \\
(0.26)\end{array}$ & $\begin{array}{l}0.013 \\
(0.15)\end{array}$ & & & \\
\hline Specific_ind_sq & $\begin{array}{l}0.000 \\
(0.02)\end{array}$ & $\begin{array}{c}-0.001^{* * *} \\
(0.03)\end{array}$ & $\begin{array}{l}0.000 \\
(0.11)\end{array}$ & & & \\
\hline Female & $\begin{array}{c}0.381^{* * *} \\
(0.02)\end{array}$ & $\begin{array}{l}0.386 \\
(0.11)\end{array}$ & $\begin{array}{l}0.086 \\
(0.67)\end{array}$ & $\begin{array}{c}0.423^{* * *} \\
(0.01)\end{array}$ & $\begin{array}{l}0.414^{*} \\
(0.08)\end{array}$ & $\begin{array}{l}0.068 \\
(0.74)\end{array}$ \\
\hline Tenure & $\begin{array}{c}0.008^{* *} \\
(0.02)\end{array}$ & $\begin{array}{c}0.012^{* *} \\
(0.03)\end{array}$ & $\begin{array}{l}0.000 \\
(0.91)\end{array}$ & $\begin{array}{l}0.003 \\
(0.31)\end{array}$ & $\begin{array}{l}0.006 \\
(0.26)\end{array}$ & $\begin{array}{l}-0.001 \\
(0.86)\end{array}$ \\
\hline MBA & $\begin{array}{c}-0.127^{* * * *} \\
(0.00)\end{array}$ & $\begin{array}{l}-0.090 \\
(0.23)\end{array}$ & $\begin{array}{c}-0.112^{* * *} \\
(0.02)\end{array}$ & $\begin{array}{c}-0.120^{* * * *} \\
(0.01)\end{array}$ & $\begin{array}{l}-0.075 \\
(0.32)\end{array}$ & $\begin{array}{c}-0.112^{* * *} \\
(0.02)\end{array}$ \\
\hline PhD_Masters & $\begin{array}{c}-0.177^{* * * *} \\
(0.00)\end{array}$ & $\begin{array}{c}-0.279^{* * * *} \\
(0.00)\end{array}$ & $\begin{array}{l}-0.074 \\
(0.23)\end{array}$ & $\begin{array}{c}-0.175^{* * * *} \\
(0.00)\end{array}$ & $\begin{array}{c}-0.260^{* * * *} \\
(0.00)\end{array}$ & $\begin{array}{l}-0.070 \\
(0.26)\end{array}$ \\
\hline МТВ & $\begin{array}{l}0.020 \\
(0.11)\end{array}$ & $\begin{array}{l}0.010 \\
(0.52)\end{array}$ & $\begin{array}{c}0.219^{* * *} \\
(0.02)\end{array}$ & $\begin{array}{l}0.022^{*} \\
(0.08)\end{array}$ & $\begin{array}{l}0.010 \\
(0.53)\end{array}$ & $\begin{array}{c}0.225^{* * * *} \\
(0.01)\end{array}$ \\
\hline Volatility & $\begin{array}{c}-0.008^{*} \\
(0.07)\end{array}$ & $\begin{array}{c}-0.019^{* * *} \\
(0.02)\end{array}$ & $\begin{array}{l}-0.001 \\
(0.83)\end{array}$ & $\begin{array}{c}-0.008^{*} \\
(0.07)\end{array}$ & $\begin{array}{c}-0.019^{* * *} \\
(0.02)\end{array}$ & $\begin{array}{l}-0.001 \\
(0.78)\end{array}$ \\
\hline Capex & $\begin{array}{c}-0.013^{* *} \\
(0.03)\end{array}$ & $\begin{array}{c}-0.030^{* * * *} \\
(0.01)\end{array}$ & $\begin{array}{l}-0.002 \\
(0.72)\end{array}$ & $\begin{array}{c}-0.015^{* *} \\
(0.02)\end{array}$ & $\begin{array}{c}-0.030^{* * * *} \\
(0.01)\end{array}$ & $\begin{array}{l}-0.003 \\
(0.69)\end{array}$ \\
\hline Firm_Perf & $\begin{array}{l}0.003 \\
(0.26)\end{array}$ & $\begin{array}{l}-0.001 \\
(0.86)\end{array}$ & $\begin{array}{c}0.010^{* * * *} \\
(0.00)\end{array}$ & $\begin{array}{l}0.004 \\
(0.13)\end{array}$ & $\begin{array}{l}0.000 \\
(0.94)\end{array}$ & $\begin{array}{c}0.010^{* * * *} \\
(0.00)\end{array}$ \\
\hline Firm size & $\begin{array}{l}0.248^{* * * *} \\
(<.0001)\end{array}$ & $\begin{array}{l}0.144^{* * * *} \\
(<.0001)\end{array}$ & $\begin{array}{l}0.421^{* * * *} \\
(<.0001)\end{array}$ & $\begin{array}{l}0.241^{* * * *} \\
(<.0001)\end{array}$ & $\begin{array}{l}0.138^{* * * *} \\
(<.0001)\end{array}$ & $\begin{array}{l}0.418^{* * * *} \\
(<.0001)\end{array}$ \\
\hline Leverage & $\begin{array}{l}-0.001 \\
(0.37)\end{array}$ & $\begin{array}{l}0.001 \\
(0.75)\end{array}$ & $\begin{array}{l}-0.001 \\
(0.79)\end{array}$ & $\begin{array}{l}-0.001 \\
(0.44)\end{array}$ & $\begin{array}{l}0.001 \\
(0.79)\end{array}$ & $\begin{array}{l}-0.001 \\
(0.79)\end{array}$ \\
\hline Dividend & $0.026^{* * * *}$ & $0.025^{*}$ & 0.019 & $0.024^{* *}$ & 0.021 & 0.021 \\
\hline
\end{tabular}

$$
\begin{aligned}
\text { Compensation }_{\mathrm{i}, \mathrm{t}+1}= & \mathrm{B}_{0}+\mathrm{B}_{1} \text { Multi_Ind }_{\mathrm{i}, \mathrm{t}}+\mathrm{B}_{2-5}(\mathrm{CEO} \text { controls })_{\mathrm{i}, \mathrm{t}}+\mathrm{B}_{6} \mathrm{MTB}_{\mathrm{i}, \mathrm{t}} \\
& +\mathrm{B}_{7} \text { Volatility }_{\mathrm{i}, \mathrm{t}}+\mathrm{B}_{8} \text { Firm_Perf }_{\mathrm{i}, \mathrm{t}}+\mathrm{B}_{9} \text { Capex }_{\mathrm{i}, \mathrm{t}}+\mathrm{B}_{10} \text { R\&D }_{\mathrm{i}, \mathrm{t}} \\
& +\mathrm{B}_{11} \text { Firm Size }_{\mathrm{i}, \mathrm{t}}+\mathrm{B}_{12} \text { Leverage }_{\mathrm{i}, \mathrm{t}}+\mathrm{B}_{13} \text { Dividends }_{\mathrm{i}, \mathrm{t}}+\mathrm{B}_{14} \mathrm{NWC}_{\mathrm{i}, \mathrm{t}} \\
& +\mathrm{B}_{15} \text { Fixed Assets }_{\mathrm{i}, \mathrm{t}}+\mathrm{e}_{\mathrm{i}, \mathrm{t}}
\end{aligned}
$$

Table 4: Impact of CEO Industry Experience on Compensation 
Firm Risk-Taking Behavior, and Ceo Compensation?

\begin{tabular}{ccccccc} 
& $(<.0001)$ & $(0.07)$ & $(0.33)$ & $(0.02)$ & $(0.12)$ & $(0.29)$ \\
NWC & 0.000 & 0.000 & 0.000 & 0.000 & 0.000 & 0.000 \\
& $(0.01)$ & $(0.00)$ & $(0.10)$ & $(0.01)$ & $(0.00)$ & $(0.09)$ \\
Fixed asset & -0.003 & 0.001 & -0.004 & -0.003 & -0.001 & -0.004 \\
& $(0.24)$ & $(0.86)$ & $(0.16)$ & $(0.26)$ & $(0.90)$ & $(0.16)$ \\
\hline Year and Ind. FEs & Yes & Yes & Yes & Yes & Yes & Yes \\
Adj. R ${ }^{2}$ & 0.197 & 0.129 & 0.376 & 0.195 & 0.124 & 0.376 \\
$\mathrm{~N}$ & 4,796 & 2,514 & 2,282 & 4,796 & 2,514 & 2,282 \\
\hline \hline
\end{tabular}

*,**, and $* * *$ indicate significance at 10\%, 5\%, and 1\% level, respectively. Numbers in parentheses are p-values.

Table 4 describes the results on how CEO specific-industry experience affects CEO compensation. Specific_Ind variable denoting the length of CEO experience in the same industry has statistically insignificant positive impact on CEO compensation considering full sample. This outcome may be driven by the fact that firms reward the CEO familiarity with the industry. Since firm-specific characteristics can play a role in designing the compensation structure, we next run the model for high-growth and low-growth firms. For both high-growth and low-growth firms, we find that CEOs with specific-industry experience receive higher compensation as they keep working in the same industry. However, the coefficients are again statistically insignificant. The results propose that the effect of CEO industry experience type on CEO compensation is weakly positive.

Table 4 also presents the impact of CEO multiple-industry experience on CEO compensation. First we run the test for the full sample. The statistically insignificant positive coefficient of Multi_Ind variable indicates that CEOs with multi-industry experience are likely to get higher compensation. This evidence weakly supports our third hypothesis which predicts that CEOs with cross-industry experience will receive pay premium. This finding is interesting because CEOs with multipleindustry experience are paid more even though hiring CEOs with cross-industry experience leads to negative impact on firm performance. This outcome is consistent with the observation of Custódio et al. (2013) who find that generalist CEOs who have accumulated more general managerial skills during their career earned 19\% more than their specialist counterparts. Our results support the existing literature suggests that CEO compensation and firm performance are weakly or insignificantly related (Barkema \& Gomez-Mejia, 1998). This weak relationship between firm performance and CEO pay is puzzling because researchers expect that CEO compensation will be aligned with firm performance to encourage CEOs to improve firm performance and to maximize their own compensation.

To see whether this relationship is influenced by the growth level of firms, we run the regression analysis separately for high-growth and low-growth firms. Interestingly, the magnitude of coefficient of multiple-industry variable for high-growth industry is close to that for the full-sample. All the coefficients are statistically insignificant. Therefore, the hypothesis predicting the positive association between CEO cross-industry experience and pay premium does not have much statistical significance. 


\section{CONCLUSION}

The CEO hiring process is an important corporate decision since CEOs can influence firms' future direction, strategy, and outcomes. Our paper investigates the effect of CEO industry experience type on firm performance, firm risk-taking behavior and CEO compensation using hand-collected CEO data over 1992-2017.

First, considering full sample, high-growh and low-growth firms, we find that the length of specific-industry experience positively affects firm performance but the impact becomes negative after a certain threshold level. We highlight that firms need to consider this in CEO hiring process. This research finding suggests that it is important to understand that hiring CEOs with specificindustry experience who have worked for long will not help company improve their long-term financial performance. This result implies that to mitigate the negative transfer of learning after a certain number of years of experience in the same industry, CEOs need to adapt to different business conditions. Moreover, it is found that for the full sample and two sub-samples, hiring CEOs with cross-industry experience is not likely to help improve firm performance, rather adversely affects firm performance. Hence, the hypothesis predicting the negative association between CEO cross-industry experience and firm performance is supported empirically.

Second, the length of CEO experience in the same industry positively affects R\&D expenditure, especially in the full and the high-growth samples. One possible explanation is that CEOs serving for long in an industry know better about industry-specific competitive conditions, industry players, resources, strategies, and technologies, which makes them more confident to invest more in R\&D. Hence, the hypothesis predicting the positive association between CEO specific-industry experience and risk-taking behavior is confirmed empirically. However, the effect becomes negative after certain threshold number of years. On the other hand, our study documents that hiring CEOs with cross-industry experience can result in reduced R\&D expenditure, regardless the growth opportunities that firms have. This supports the hypothesis which predicts that CEOs with cross-industry experience will invest less in R\&D expenditure.

Third, a notable finding is that the length of CEO experience in the same industry has statistically insignificant positive impact on CEO compensation for all three samples. These weakly positive associations may be due to that firms value successful CEOs with specific-industry experience and they reward the incoming CEOs with higher compensation. In addition, CEOs having crossindustry experience are also likely to get higher compensation because of the competitive executive labor market. This evidence weakly supports the hypothesis which predicts that CEOs with crossindustry experience will receive pay premium.

One important implication is that to optimize firm performance, firms should hire CEOs with the length of specific-industry experience not beyond the threshold levels. We contribute to the literature by examining the impact of the type of CEO industry experience (i.e., specific-industry vs. cross-industry experience) on firm outcomes and CEO compensation. Our findings have important implications not only for board of directors who make executive hiring decisions but also for corporate strategists in predicting future strategic moves of the company's rivals. Future research initiatives can be taken to investigate the variation in how CEO industry experience type affects corporate outcomes and CEO compensation across industries. 


\section{REFERENCES}

Bailey, E. E., \& Helfat, C. E. (2003). External management succession, human capital, and firm performance: An integrative analysis. Managerial and Decision Economics, 24(4), 347-369.

Barkema, H. G., \& Gomez-Mejia, L. R. (1998). Managerial compensation and firm performance: A general research framework. Academy of Management journal,41(2), 135-145. https://doi.org/10.2307/257098

Barker, V. L. III., \& Mueller, G. C. (2002). CEO characteristics and firm R\&D spending. Management Science, 48(6), 782-801.

Benmelech, E., \& Frydman, C. (2015). Military CEOs. Journal of Financial Economics, 117(1), 43-59. https://doi.org/10.1016/j.jfineco.2014.04.009

Bernile, G., Bhagwat, V., \& Rau, P. R. (2017). What doesn't kill you will only make you more risk-loving: Early-life disasters and CEO behavior. The Journal of Finance, 72(1), 167-206. https://doi.org/10.1111/jofi.12432

Brockman, P., Krishnan, G., Lee, H. S., \& Salas, J. M. (2019). Implications of CEO succession origin and in-house experience for audit pricing. Journal of Accounting, Auditing \& Finance, 1-32. https://doi.org/10.1177/0148558X19832104

Bragaw, N. A., \& Misangyi, V. F. (2017). The value of CEO mobility: contextual factors that shape the impact of prior CEO experience on market performance and CEO compensation. Human Resource Management, 56(2), 243-265. https://doi.org/10.1002/hrm.21737

Cain, M. D., \& McKeon, S. B. (2016). CEO personal risk-taking and corporate policies. Journal of Financial and Quantitative Analysis, 51(1), 139-164. https://doi.org/10.1017/S0022109016000041

Calvet, L. E., \& Sodini, P. (2014). Twin Picks: Disentangling the Determinants of Risk-Taking in Household Portfolios. The Journal of Finance, 69(2), 867-906. https://doi.org/10.1111/jofi.12125

Chahyadi, C., \& Wineka, P. (2019). How does CEO career origin influence firm risk-taking? Journal of Accounting and Finance, 19(4), 77-96. https://doi.org/10.33423/jaf.v19i4.2174

Chen, W., \& Miller, K. D. (2007). Situational and institutional determinants of firms' R\&D search intensity. Strategic Management Journal, 28, 369-381. https://doi.org/10.1002/smj.594

Custódio, C., Ferreira, M. A., \& Matos, P. (2013). Generalists versus specialists: Lifetime work experience and chief executive officer pay. Journal of Financial Economics, 108(2), 471-492. https://doi.org/10.1016/j.jfineco.2013.01.001

Dokko, G., Wilk, S. L., \& Rothbard, N. P. (2009). Unpacking prior experience: How career history affects job performance. Organization Science, 20(1), 51-68. https://10.1287/orsc.1080.0357

Drobetz, W., Von Meyerinck, F., Oesch, D., \& Schmid, M. (2018). Industry expert directors. Journal of Banking \& $\quad$ Finance, 92, 195-215. https://doi.org/10.1016/j.jbankfin.2018.04.019

Faccio, M., Marchica, M. T., \& Mura, R. (2016). CEO gender, corporate risk-taking, and the efficiency of capital allocation. Journal of Corporate Finance, 39, 193-209. https://doi.org/10.1016/j.jcorpfin.2016.02.008

Faleye, O., Hoitash, R., \& Hoitash, U. (2018). Industry expertise on corporate boards. Review of Quantitative Finance and Accounting, 50(2), 441-479.

Fama, E. F., \& French, K. R. (1993). Common risk factors in the returns on stocks and bonds. Journal of Financial Economics, 33, 3-56.

Fee, C. E., \& Hadlock, C. J. (2003). Raids, rewards, and reputations in the market for managerial talent. The Review of Financial Studies, 16(4), 1315-1357. https://doi.org/10.1093/rfs/hhg031 
Frydman, C., \& Jenter, D. (2010). CEO compensation. Annual Review of Financial Economics, 2(1), 75-102. https://doi.org/10.1146/annurev-financial-120209-133958

Graham, J. R., Harvey, C. R., \& Puri, M. (2013). Managerial attitudes and corporate actions. Journal of Financial $\quad$ Economics, 109(1), 103-121. https://doi.org/10.1016/j.jfineco.2013.01.010

Hambrick, D. C., \& Mason, P. A. (1984). Upper echelons: The organization as a reflection of its top managers. Academy of Management Review, 9(2), 193-206. https://doi.org/10.2307/258434

Hamori, M., \& Koyuncu, B. (2015). Experience matters? The impact of prior CEO experience on firm performance. Human Resource Management, 54(1), 23-44. https://doi.org/10.1002/hrm.21617

Hoskisson, R. E., Chirico, F., Zyung, J., \& Gambeta, E. (2017). Managerial risk-taking: A multitheoretical review and future research agenda. Journal of Management, 43(1), 137-169. https://doi.org/10.1177/0149206316671583

Karaevli, A. (2007). Performance consequences of new CEO 'Outsiderness': Moderating effects of pre-and post-succession contexts. Strategic Management Journal,28(7), 681-706. https://doi.org/10.1002/smj.589

Malmendier, U., \& Tate, G. (2005). CEO overconfidence and corporate investment. The Journal of Finance, 60(6), 2661-2700. https://doi.org/10.1111/j.1540-6261.2005.00813.x

Malmendier, U., Tate, G., \& Yan, J. (2011). Overconfidence and early-life experiences: the effect of managerial traits on corporate financial policies. The Journal of Finance, 66(5), 1687-1733. https://doi.org/10.1111/j.1540-6261.2011.01685.x

Mansfield, E. (1968). Industrial Research and Technological Innovation. Norton, New York.

Mueller, P., Georgakakis, D., \& Ruigrok, W. (2017). Jack of all trades or master of none? CEO experience variety and firm performance. Academy of Management Proceedings, 2017(1), 17662.

Murphy, K. J., \& Zabojnik, J. (2004). CEO pay and appointments: A market-based explanation for recent trends. American Economic Review, 94(2), 192-196.

Ryan Jr, H. E., \& Wiggins III, R. A. (2002). The interactions between R\&D investment decisions and compensation policy. Financial Management, 5-29. https://doi.org/10.2307/3666319

Wang, G., Holmes Jr, R. M., Oh, I. S., \& Zhu, W. (2016). Do CEOs matter to firm strategic actions and firm performance? A meta-analytic investigation based on upper echelons theory. Personnel Psychology, 69(4), 775-862. https://doi.org/10.1111/peps.12140

Yung, K., \& Chen, C. (2018). Managerial ability and firm risk-taking behavior. Review of Quantitative Finance and Accounting, 51(4), 1005-1032. https://doi.org/10.1007/s11156-017$\underline{0695-0}$

Zhang, W. (2015). R\&D investment and distress risk. Journal of Empirical Finance, 32, 94-114. https://doi.org/10.1016/i.jempfin.2015.03.009 
Appendix 1: Definition of Variables

\begin{tabular}{cl}
\hline \hline Variable & \multicolumn{1}{c}{ Description } \\
\hline Multi_Ind & Equals one if the CEO has more than one industry experience, and zero otherwise \\
Specific_Ind & The number of years in the same industry (based on three-digit SIC code) \\
Specific_Ind_Sq & Square of Specific_ind variable \\
Female & Equals one if the CEO is female, and zero otherwise \\
Tenure & The number of years the CEO served in the current position \\
MBA & Equals one if the CEO has an MBA, and zero otherwise \\
PhD_Masters & Equals one if the CEO has either master's or PhD, and zero otherwise \\
MTB & Total assets less common equity less deferred taxes balance sheet plus market value \\
& of equity divided by total assets \\
Volatility & Sum of the squared residual from the Fama-French's (1993) three-factor model \\
Firm_Perf & Operating Income after depreciation divided by total assets \\
Capex & Capital expenditure divided by total assets \\
R\&D & Research and development expense to total sales \\
Firm Size & Natural logarithm of total asset \\
Leverage & Total long-term debt divided by total assets \\
Dividend & The proportion of dividends from preferred and common stock to total assets \\
NWC & Net working capital \\
Fixed Asset & Fixed assets divided by total assets \\
Compensation & Natural logarithm of total compensation \\
\hline \hline
\end{tabular}

